\title{
New approaches to studying morphological details of intramolluscan stages of Angiostrongylus vasorum
}

\author{
Novas abordagens para estudo morfológico dos estágios intramoluscos de \\ Angiostrongylus vasorum
}

Cíntia Aparecida de Jesus Pereira1; Aytube Lucas Coaglio'; Luciano Santos Capettini²; Raphael Becattini; Ana Paula Pereira Neves Ferreira'; Andreia Costa1; Lanuze Mozzer Soares'; Laura Lúcia Oliveira3\%; Walter dos Santos Lima1* (1)

\begin{abstract}
${ }^{1}$ Departamento de Parasitologia, Instituto de Ciências Biológicas, Universidade Federal de Minas - UFMG, Belo Horizonte, MG, Brasil ${ }^{2}$ Departamento de Farmacologia, Instituto de Ciências Biológicas, Universidade Federal de Minas - UFMG, Belo Horizonte, MG, Brasil ${ }^{3}$ Departamento Zootecnia, Universidade Estadual de Montes Claros - UNIMONTES, Janaúba, MG, Brasil
\end{abstract}

How to cite: Pereira CAJ, Coaglio AL, Capettini LS, Becattini R, Ferreira APPN, Costa A, et al. New approaches to studying morphological details of intramolluscan stages of Angiostrongylus vasorum. Braz J Vet Parasitol 2020; 29(2): e000420. https://doi. org/10.1590/S1984-29612020044

\begin{abstract}
Angiostrongylus vasorum is a pulmonary artery parasite of domestic and wild canid. On molluscs, intermediate host, first stage larvae (L1) are found after the first day of infection, in the $8^{\text {th }} \mathrm{L} 2$ and in the $30^{\text {th }} \mathrm{L} 3$. It was evaluated L1, $\mathrm{L} 2$ and $\mathrm{L} 3$ recovered by Baermann technique from Achatina fulica infected with $1000 \mathrm{~L} 1$. Fifty larvae/stage were incubated with antibodies anti- $\beta$-tubulin, anti-a-tubulin, anti- $\alpha$-actin, anti- $\beta$-actin and anti-collagen, and then with Alexa 633. Fifty larvae/stage were observed with picrosirius red and Oil Red $\mathrm{O}$. It was also observed in the anterior region of L1 the beginning of the chitinous stems development, in the initial portion of the intestine and genital primordium. In L2 anterior region, the papillae, chitinous canes juxtaposed to the mouth and intestines bigger than L1. The L3 musculature is well defined, next to the chitinous stems, there are two round distally arranged from each other. It was observed the whole extension of the intestine genital primordium and intense cellularity in the L3 distal portion. With the picrosirius red the L1, L2 and L3 musculature could be observed, as the nerve ganglia on L3. Oil Red O revealed that L1, L2 and L3 store energy on lipid droplets.
\end{abstract}

Keywords: Angiostrongylus vasorum, Achatina fulica, morphology, antibodies, picrosirius red, Oil Red O.

\section{Resumo}

Angiostrongylus vasorum é um parasito de artérias pulmonares dos canídeos domésticos e silvestres. Nos moluscos, hospedeiros intermediários, encontram-se no primeiro dia após a infecção, larvas de primeiro estágio (L1), ao $8^{\circ} \mathrm{L} 2$ e ao $30^{\circ} \mathrm{L} 3$. Avaliou-se L1, L2 e L3 recuperadas pela técnica de Baermann de Achatina fulica infectada com 1.000 L1. Incubou-se 50 larvas/estádio com anticorpos anti- $\beta$-tubulina, anti-a-tubulina, anti- $\beta$-actina e anti-colágeno e, em seguida, com anticorpo Alexa 633. Observaram-se também 50 larvas/estádio com picrosirius red e Oil Red $\mathrm{O}$, na região anterior da L1, o início do desenvolvimento de hastes quitinosas, a porção inicial do intestino e o primórdio genital. Na região anterior de L2, papilas, bastões quitinosos justapostos à boca e ao intestino maior que em L1. A musculatura de L3 é bem desenvolvida, próximo às hastes quitinosas, há duas estruturas redondas dispostas distalmente uma da outra. Observaram-se também toda a extensão do intestino, o primórdio genital e a intensa celularidade na porção distal da L3. Com o picrosirius red observou-se a musculatura de L1, L2 e L3, assim como, gânglios nervosos na L3. Oil Red O revelou que L1, L2 e L3 armazenam energia em gotículas lipídicas.

Palavras-chave: Angiostrongylus vasorum, Achatina fulica, morfologia, anticorpos, picrosirius red, Oil Red $\mathrm{O}$.

Received February 3, 2020. Accepted April 24, 2020.

Financial support: Minas Gerais Research Foundation (Fundação de Amparo à Pesquisa do Estado de Minas Gerais - FAPEMIG), (WSL, grant number 18898), the National Council for Scientific and Technological Development (Conselho Nacional de Desenvolvimento Científico e Tecnológico - CNPq) (WSL, grant number 480469/2012-1).

*Corresponding author: Walter dos Santos Lima. E-mail: wlima@icb.ufmg.br 


\section{Introduction}

Angiostrongylus vasorum affects the right ventricle of the heart and the pulmonary arteries in dogs, red foxes and other canids (Mozzer \& Lima, 2015). In humans, A. cantonensis causes eosinophilic meningitis and A. costaricensis triggers abdominal eosinophilic ileocolitis (Thiengo et al., 2013). The complete life cycle of these nematodes takes place in their definitive hosts, which are usually rodents. The eggs settle in the intestinal submucosa, while the adults lodge in the mesenteric arteries.

Achatina fulica the African giant snail was introduced in Brazil in 1980, currently its present in 23 Brazilian states including Minas Gerais (Barçante et al., 2005; Thiengo et al., 2013). It was found naturally infected with A. cantonensis, in Pernambuco, Rio de Janeiro, Santa Catarina, Espírito Santo and Amazonas (Thiengo et al., 2013). The eosinophilic meningitis cases in Espírito Santo are related to the ingestion of these molluscs. Achatina fulica also can be infected with $A$. costaricensis and A. vasorum (Neuhauss et al., 2007; Coaglio et al., 2016). In Brazil A. fulica are found naturally infected with other nematodes of importance in the veterinary field, Aelurostrongylus abstrusus, a cat lung parasite, Rhabditis sp. and Strongyluris sp., parasites found in the intestine of amphibians and reptiles (Oliveira et al., 2010). Knowing this, the participation of $A$. fulica in the context of public health must be proposed, as there are reports of natural infection related to this molluscs in several regions of Brazil, as such, it is important to know the development of the different stages of mollusc nematode parasite, as the knowledge gathered could help in creating control strategies.

Treatment of angiostrongyliasis with nematicides generally does not produce good results, and new therapies are extremely necessary. Although recent "omic" data on parasitic nematodes accelerate the identification of potential drug targets (Mccoy et al., 2017), the validation of these targets in functional experiments remains a challenge because few techniques allow functional characterization. Therefore, the use of different morphological markers for parasitic nematodes may help morphological observations of these nematodes and may contribute to "omic" studies.

In the present study, we analyzed the morphology and morphometry of $L 1, L 2$, and $L 3$ larvae of $A$. vasorum recovered from Achatina fulica by assessing the cytoskeleton, connective tissue and lipid distribution of these larvae using cytoskeleton and collagen antibodies and staining with picrosirius red and Oil Red O, respectively.

\section{Materials and Methods}

\section{Obtaining intramolluscan stages of Angiostrongylus vasorum}

The strain of $A$. vasorum that was used is maintained in dogs at the experimental kennel of the Institute of Biological Sciences of the Federal University of Minas Gerais (ICB/UFMG) (Lima et al., 1985). To obtain L1 larvae, feces collected from the dogs that maintain the strain were subjected to the Baermann technique. This study and maintenance of the strain in animal hosts was approved by the ethics committee for animal use of UFMG (CEUA/UFMG) under the number 147/2011.

Then, $1 \mathrm{~mL}$ of water containing $1000 \mathrm{~L} 1$ was placed in each of specimen of infection containers of width $5 \mathrm{~cm}$ and height $5 \mathrm{~cm}$. Specimens of the mollusc Achatina fulica of mean size of $4 \mathrm{~cm}$ were individually introduced into each infection container (one per container) so that they would be exposed to L1. They were left there for $24 \mathrm{~h}$, at the room temperature of $23^{\circ} \mathrm{C}(\mathrm{RT})$. After this period, these molluscs were transferred to a rectangular terrarium containing autoclaved soil supplemented with calcium carbonate. Water and lettuce were provided ad libitum. The terrariums were cleaned three times a week.

The remaining larvae in the infection containers were quantified as described by Pereira et al. (2006). Fifty molluscs were used to recover L1 (1 day post-infection, dpi), 50 to recover L2 (8 dpi) and 50 to recover L3 (30 dpi). The L1, L2 and L3 larvae were recovered under a Baermann's technique, as proposed by Coaglio et al. (2016).

\section{Morphological evaluation of $A$. vasorum larval stages}

350 larvae per stage (L1, L2 and L3) were recovered with the help of a stereoscopic microscope (25x) and were stored in a $2 \mathrm{~mL}$ polypropylene tube containing $300 \mu \mathrm{l}$ of PBS. Then, $900 \mu \mathrm{l}$ of $4 \%$ paraformaldehyde was added and the samples were incubated for $24 \mathrm{~h}$ at $4{ }^{\circ} \mathrm{C}$. To remove excess fixative, the samples were washed $3 \mathrm{x}$ with water by means of centrifugation at $180 \mathrm{~g}$ for $10 \mathrm{~min}$. At the end of this, the larvae were resuspended in $900 \mu \mathrm{l}$ 
water and used as described below. 50 larvae per stage (L1, L2 and L3) were used as a control that was detected by means of ligth microscopy.

To allow small pores to be formed in the cuticle of the nematodes, the tubes with the larval stages were placed in a $10 \mathrm{ml}$ beaker with $95 \%$ ethyl alcohol for $4 \mathrm{~min}$ at $-80^{\circ} \mathrm{C}$. Subsequently, the tubes were placed in water for $10 \mathrm{~min}$ at RT, followed by slight agitation on a microplate shaker for 30 min at RT. After this period, the samples were centrifuged at $450 \mathrm{~g}$ for $1 \mathrm{~min}$. After this procedure, $0.5 \%$ saponin was added and the samples were incubated for $10 \mathrm{~min}$ at RT under gentle shaking. They were then washed $3 \mathrm{x}$ with water by means of centrifugation at $180 \mathrm{~g}$ for 10 min.

Next, each sample received $200 \mu \mathrm{l}$ of BTB (borate triton $\beta$-mercaptoethanol solution_(Borate buffer/25mM; Triton X-100/0.5\%; $\beta$-mercaptoethanol/3\% in the final concentration) and was incubated for $1 \mathrm{~h}$ at RT, under gentle shaking (Biomixer Ts-2000A shaker). Subsequently, the samples were washed with BTB by means of centrifugation at $450 \mathrm{~g}$ for $1 \mathrm{~min}$. After a third hour with BTB, the samples were again washed $3 x$ by means of centrifugation at $220 \mathrm{~g}$ for 2 min and, following the removal of BTB, each sample was resuspended in borate triton (BT) solution_(Borate buffer/25mM; Triton X-100/0.5\% in the final concentration).

Following the removal of excess BT as described above, the cytoskeleton content and distribution of the larvae (L1, L2 and L3) was investigated. Fifty larvae of each stage were incubated individually with $50 \mu$ lof each of the following primary antibodies (Santa Cruz Biotechnology) diluted 1:500 in PBS containing bovine serum albumin (BSA): anti- $\beta$-actin (sc 69879), anti-a-tubulin (sc 5286), anti- $\beta$-tubulin (mouse-sc 55529) and anti-collagen (Cat. No. sc-9855, Santa Cruz Biotechnology, CA). The samples were incubated overnight at $4{ }^{\circ} \mathrm{C}$ under gentle agitation. They were then centrifuged at $220 \mathrm{~g}$ for $2 \mathrm{~min}$. The supernatant was discarded and $250 \mu \mathrm{l}$ of the blocking solution (4\% BSA/PBS) was added for a further $1 \mathrm{~h} 30 \mathrm{~min}$ at $4{ }^{\circ} \mathrm{C}$, under gentle shaking. Excess dye was removed by centrifuging the samples at $220 \mathrm{~g}$ for $2 \mathrm{~min}$. The procedure was repeated four times. Then, $50 \mu \mathrm{l}$ of the secondary antibody conjugated to Alexa 633 (goat anti-mouse, Invitrogen/Cat. No. A-21052) diluted at 1:500 in PBS was added to the samples and incubated for $2 \mathrm{~h}$ in the dark at RT, under gentle shaking. To remove the excess antibodies, the samples were washed $4 \mathrm{x}$ with PBS at $220 \mathrm{~g}$ for $2 \mathrm{~min}$. The samples were mounted between slides and coverslips and images were captured using an epifluorescence microscope_model Axiovert 200M APOTOME (Carl Zeiss, Germany).

To investigate the lipid content and distribution, 50 larvae of each stage were incubated with the Oil Red $O$ dye at a ratio of 3:1 for $24 \mathrm{~h}$ at RT. The larvae were mounted between a slide and a coverslip and observed under an Olympus ${ }^{\circledR}$ BX41 ligth microscope coupled to an Olympus ${ }^{\circledR}$ DP12 digital camera.

Following this, picrosirius red (Junqueira et al., 1979) (3:1 in PBS) was added to 50 larvae of each stage for $24 \mathrm{~h}$ at $4{ }^{\circ} \mathrm{C}$. The larvae were then centrifuged at $220 \mathrm{~g}$ in PBS $2 x$ to remove the excess dye. The samples were mounted between slides and coverslips, and images were obtained via epifluorescence microscopy with Apotome, as described above, because picrosirius red can be detected at the red wavelength.

\section{Results}

Morphological characterization of intramolluscan larval stages of Angiostrongylus vasorum

\section{First-stage larvae (L1)}

The LI specimens that were recovered were thin and transparent, measuring $332 \pm 12 \mu \mathrm{m}$ in length and $11 \pm 1 \mu \mathrm{m}$ in width. The anterior end was rounded and the tail was curved ventrally with an unguiform appendage, as seen using ligth microscopy (Figure 1A).

Anti-a-tubulin antibodies showed the nerve ring, the intestinal region and the anal opening (Figure 1B). Although some structures were not identified through this antibody, there were two oval structures next to the chitinous rods that were not detected by means of ligth microscope. These structures measured $5 \mu \mathrm{m}^{2}$, with an average of $2 \mu \mathrm{m}$ in length and $0.5 \mu \mathrm{m}$ in width (Figure 1B). The nerve ring was located $70 \mu \mathrm{m}$ from the anterior end of the larva and was $6 \mu \mathrm{m}$ in length and $7 \mu \mathrm{m}$ in width (Figure 1B). The width of the initial portion of the intestine was $6 \mu \mathrm{m}$ and the total length of the intestine was $158 \mu \mathrm{m}$ (Figure 1B).

Anti- $\beta$-tubulin antibodies labelled the chitinous rods and intestine well, while the nerve ring was poorly shown by them. The chitinous rods measured $7 \mu \mathrm{m}$ in length and the anal opening was located $25 \mu \mathrm{m}$ from the final 

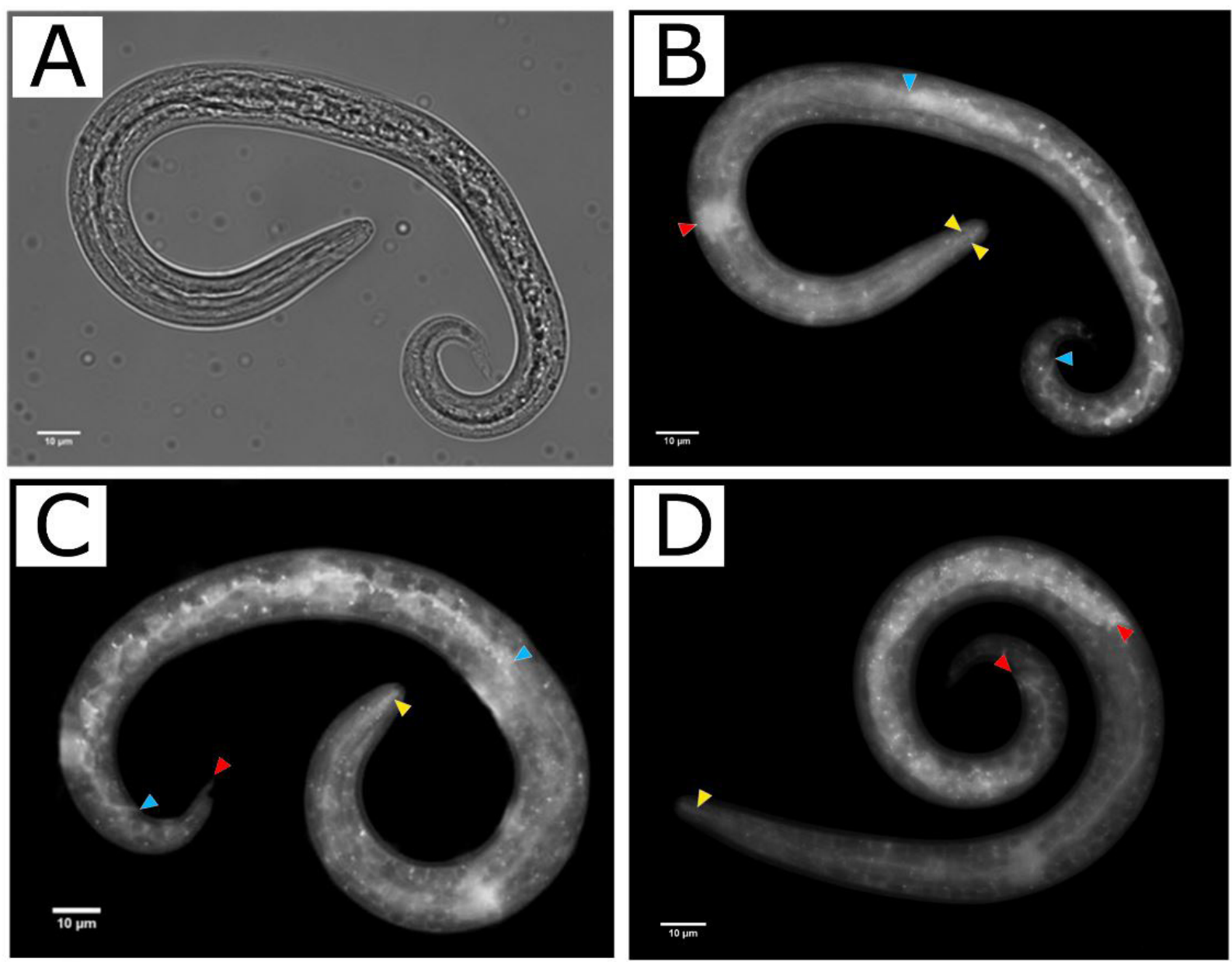

Figure 1. First-stage larva of Angiostrongylus vasorum. (A) ligth field microscopy image of L1; (B) L1 labeled with anti-a-tubulin antibodies: red arrowhead indicates nerve ring; yellow arrowhead indicates two oval structures; the intestine is indicated as between the blue arrowheads; (C) L1 labeled with anti- $\beta$-tubulin antibodies: yellow arrowhead indicates the chitinous rods; the intestine is indicated as between the blue arrowheads; red arrowhead indicates the tip of the tail; (D) L1 labeled with anti-collagen antibodies: yellow arrowhead indicates the chitinous rods; intestine is indicated as between the red arrowheads.

portion of the tail. It was also revealed that the distance from the tip of the tail to the slit that is present in this region was $4 \mu \mathrm{m}$ (Figure 1C).

Using anti-collagen antibodies, collagen fibers were detected in the structures of L1, including the intestine, chitinous rods and nerve ring (Figure 1D). The distance from the sheath of L1 to the wall of the body was $1 \mu \mathrm{m}$ (Figure 1D). When labeled with anti-a-tubulin, anti-collagen and anti- $\beta$-tubulin, L1 showed prominence of the posterior portion, especially the intestine (Figure 1B-D).

Initially, with epifluorescence microscopy without Apotome, staining with picrosirius red only revealed a few structures. However, after using the Apotome, it was possible to detect the chitinous rods, the nerve ring, the esophagus and the musculature around it, the intestine and the genital primordium of L1. Picrosirius red staining showed an oval-shaped genital primordium measuring $6 \mu \mathrm{m}$ in length and located at $69 \mu \mathrm{m}$ from the anal opening and $99 \mu \mathrm{m}$ from the tip of the tail. The L1 musculature was $2 \mu \mathrm{m}$ thick and had small oval-shaped cellular structures of $3 \mu \mathrm{m}$ in length (Figure $2 \mathrm{~A}$ ). Staining with Oil Red $\mathrm{O}$ showed intense presence of lipids throughout the body of L1 (Figure 2B).

\section{Second-stage larvae (L2)}

The L2 larvae were located in the tissues of the intermediate host and were characterized by being slightly mobile, arched (' $\mathrm{C}$ ' shaped) and brownish in color due to the presence of granules inside the intestinal cells. They measured about $420 \pm 23 \mu \mathrm{m}$ in length and $12 \pm 2 \mu \mathrm{m}$ in width and had two sheaths that occupied the entire interior space, as shown by ligth microscopy (Figure 3A). 

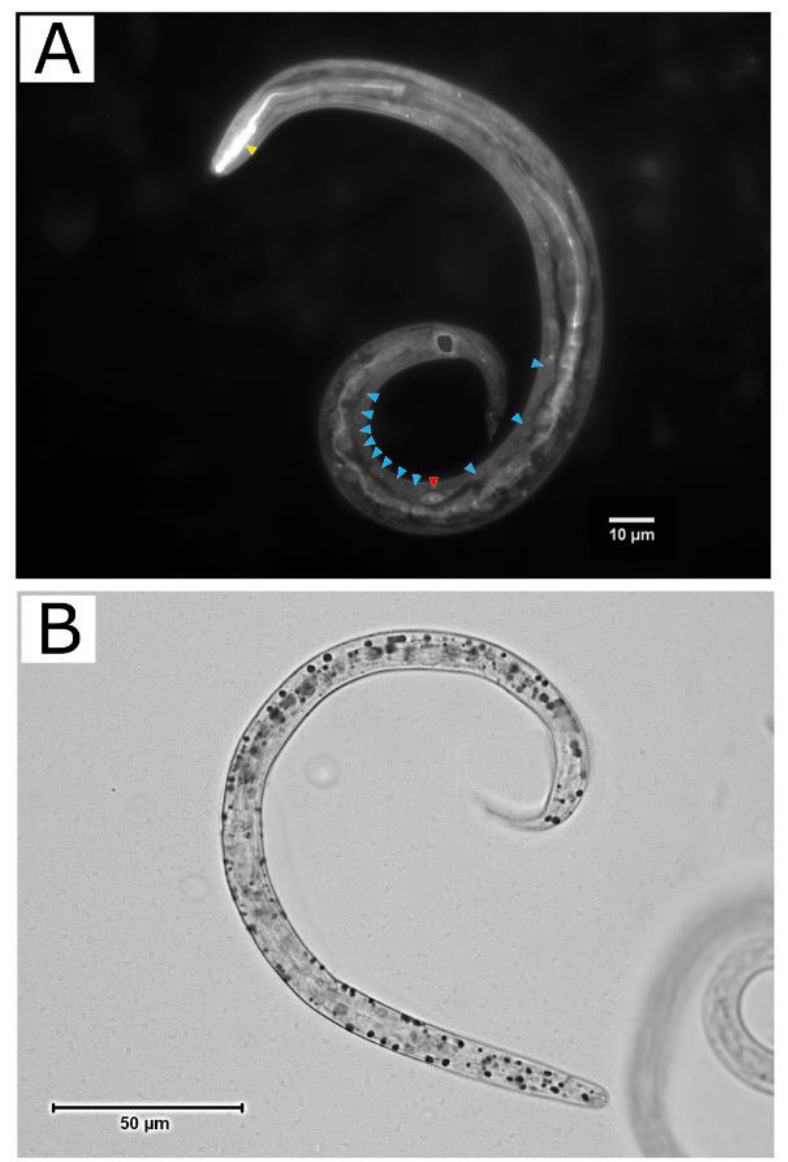

Figure 2. First-stage larva of Angiostrongylus vasorum. (A) L1 stained with picrosirius red: yellow arrowhead indicates the chitinous rods; red arrowhead indicates the genital primordium; blue arrowhead indicates the general appearance of muscle cells; (B) L1 stained with Oil Red O, showing lipid droplets (dark spots).

Anti-a-tubulin antibodies revealed an esophagus of $147 \mu \mathrm{m}$ in length. When dilated, the esophagus measured $12 \mu \mathrm{m}$ in width and $27 \mu \mathrm{m}$ in length. The nerve ring in $\mathrm{L} 2$ had a rectangular shape, measuring $15 \mu \mathrm{m}$ in width, and was located $80 \mu \mathrm{m}$ away from the tip of the anterior portion. The anti-a-tubulin antibodies also showed that the intestine as a compact mass of $27 \mu \mathrm{m}$ in width, occupying almost the whole width of the larva, differently from L1, whose intestine was observed as a filament (Figure 3B).

Anti- $\beta$-tubulin antibodies marked the intestine more intensely than the esophagus. Every segment of the intestine of $L 2$ was formed by small rounded cells (Figure 3C). Only the gut became labelled with anti- $\beta$-actin antibodies and, when the Apotome was used, we observed two small papillae in the anterior portion, about $2 \mu \mathrm{m}$ wide and $5 \mu \mathrm{m}$ apart from each other. The oral opening measured $15 \mu \mathrm{m}$ (Figure 4C).

The esophageal wall stained with picrosirius red (Figure 4A). This morphological detail was not observed when L2 were incubated with the antibodies. The intestine was not shown with this dye when epifluorescence was used alone; however, after using the Apotome attachment, we were able to view the structures of the intestine, along with the esophageal composition, the excretory pore ( $30 \mu \mathrm{m}$ in length), the genital primordium and the anal opening (Figure 4A). Picrosirius red staining also revealed that the genital primordium was not as well-defined in L2 as it is in L1. Rather, it was a cluster of cells, $17 \mu \mathrm{m}$ in length and $6 \mu \mathrm{m}$ in width, located $180 \mu \mathrm{m}$ away from the end of the tail (Figure 4A). Lipids were recognized by means of the Oil Red O dye, throughout the body of L2 (Figure 4B).

\section{Third-stage larvae (L3)}

L3 appeared free from sheaths and was clearer and more transparent than the other stages, with two chitinous rods arranged longitudinally at the anterior end. The tail ended with a digitiform appendix, measuring about $470 \pm 25 \mu \mathrm{m}$ in length and $19 \pm 1 \mu \mathrm{m}$ in width, as shown by ligth microscopy (Figure 5A).

Anti-collagen antibodies also revealed the nerve ring (Figure 5B). 

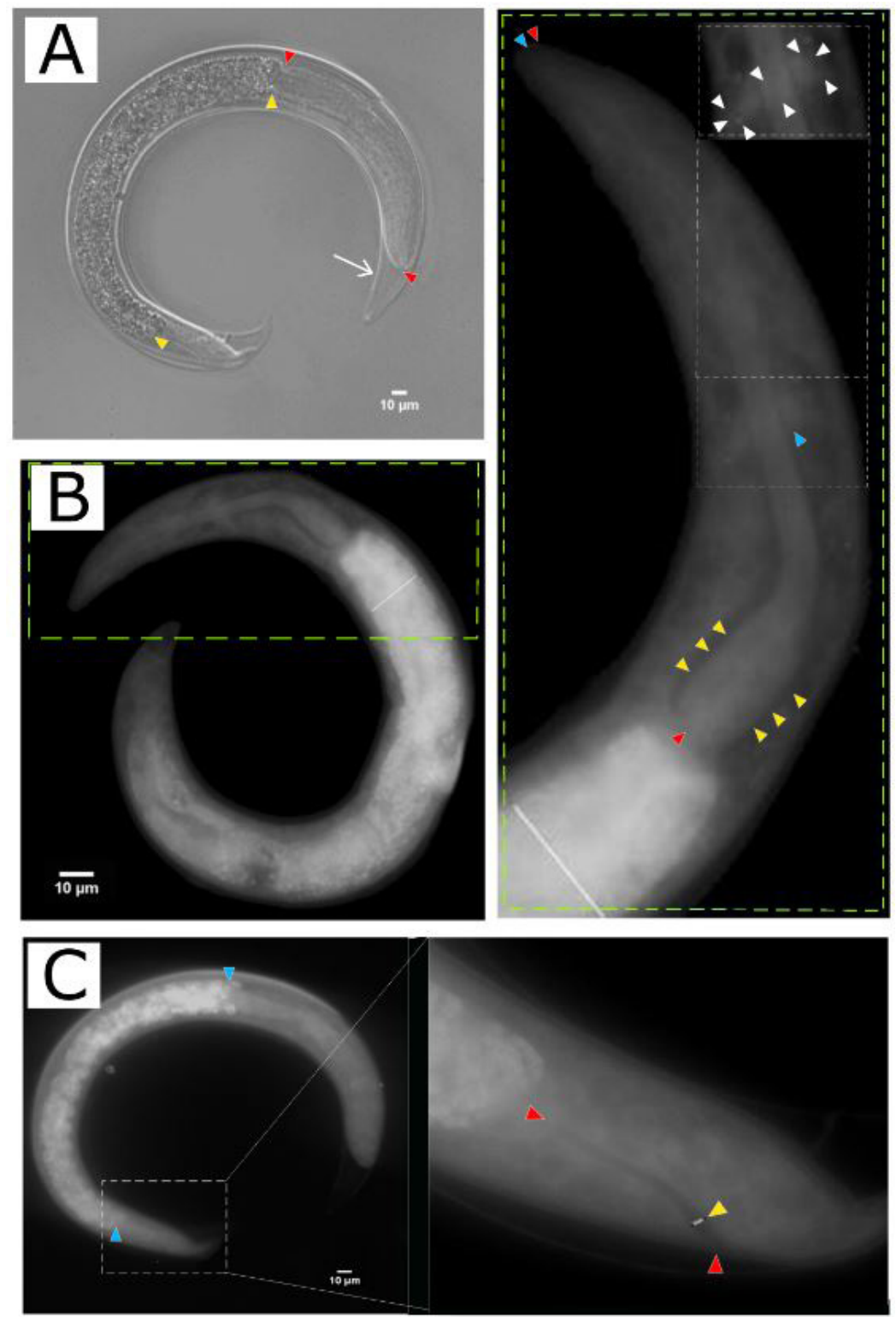

Figure 3. Second-stage larva of Angiostrongylus vasorum. (A) " $\mathrm{C}$ "-shaped L2 presenting the second sheath (thin white arrow) in bright field: distance from the mouth to the end of the esophagus is indicated as between the red arrowheads; the intestine is indicated as between the yellow arrowheads; (B) Labeling with anti-a-tubulin antibodies: dotted green indicates the esophagus; yellow arrowheads indicate a dilation in the final portion of the esophagus; red arrowheads indicate the distance from the mouth to the end of the esophagus; blue and white arrowheads indicate the nerve ring; intestine with width indicated by the white bar; (C) L2 with anti- $\beta$-tubulin antibodies: the intestine is indicated as between the blue arrowheads; the anal opening at the end of the intestine is indicated as between the red arrowheads; yellow arrowhead indicates the length of the anal opening.

Anti-a-tubulin antibodies revealed the chitinous rods, nerve ring, esophagus and intestine. The genital primordium and anal opening became labelled less intensely than was observed when the other stages were analyzed. The lateral cell layer was composed of rounded cells (Figure 5C and 5D). The $13 \mu \mathrm{m}$-long chitinous rods were $2 \mu \mathrm{m}$ apart and presented a bulb at their base measuring $1.5 \mu \mathrm{m}$ in length and $1 \mu \mathrm{m}$ in width. The nerve ring was $64 \mu \mathrm{m}$ away from the anterior end of the larvae, measuring $18 \mu \mathrm{m}$ in length by $8 \mu \mathrm{m}$ in width (Figure 5D). The length of the esophagus was $192 \mu \mathrm{m}$ and it had a dilation in the final portion, which was $46 \mu \mathrm{m}$ long and $20 \mu \mathrm{m}$ wide (Figure 5D). The initial width of the intestine (19 $\mu \mathrm{m}$ in length) could be noted in the portion that attached to the esophagus: $260 \mu \mathrm{m}$ in length and $20 \mu \mathrm{m}$ in width.

Regarding anti- $\beta$-tubulin antibodies, a-tubulin marked the chitinous rods, nerve ring intestine and the genital primordium (Figure 5C and 5D). The Oil Red O dye weakly stained the gut (Figure 5E). 

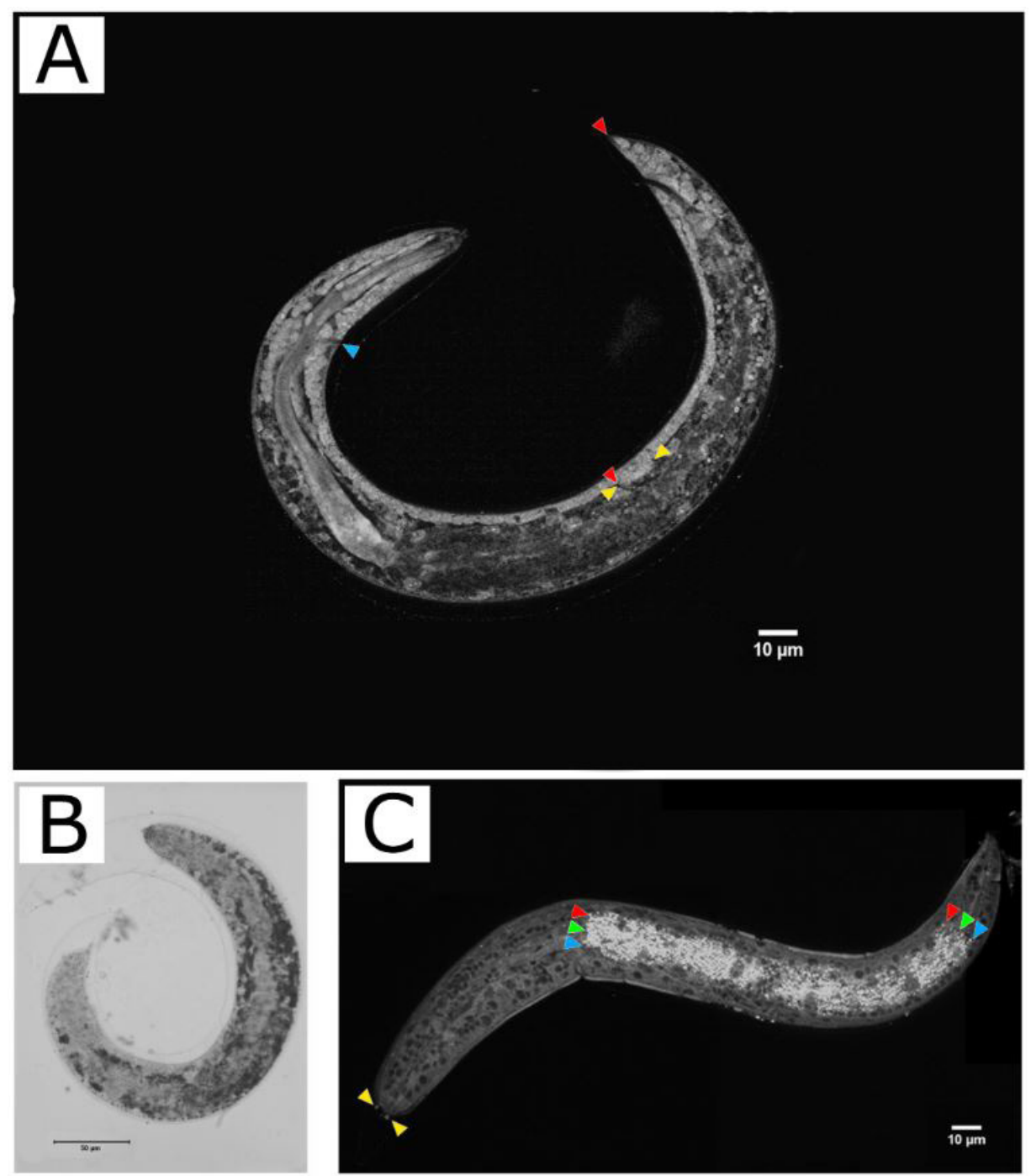

Figure 4. Second-stage larva of Angiostrongylus vasorum. (A) L2 stained with picrosirius red: the genital primordium is indicated as between the yellow arrowheads; the distance from the genital primordium to the final portion of the tail is indicated as between the red arrowheads; the excretory pore is indicated by the blue arrowhead; (B) L2 stained with Oil Red O; dark spots show lipid droplets; (C) Intestine viewed using the Apotome attachment: the anti-collagen antibody is indicated as between the red arrowheads; the anti- $\beta$-tubulin antibodies are indicated as between the green arrowheads and the anti- $\beta$-actin antibodies are indicated as between the blue arrowheads. Two spherical structures at the anterior end of the larva that were revealed with anti- $\beta$-actin antibodies are indicated as between the yellow arrowheads.

Staining with picrosirius red dye revealed nerve ganglia, which were oval-shaped structures spaced symmetrically from the esophagus (Figure 6A and 6B). The dye also showed that nerve cells existed in the anterior region and were similar to the amphidial pouch found in some adult nematodes (Figure 6A). Furthermore, the genital primordium was $156 \mu \mathrm{m}$ away from the end of the tail: it was $21 \mu \mathrm{m}$ in length by $6 \mu \mathrm{m}$ in width and was composed of 15 rounded cells (Figure 6B). The excretory pore (32 $\mu \mathrm{m}$ in length) extended into the esophagus and was located $66 \mu \mathrm{m}$ away from the oral opening (Figure 6B). The labeling also revealed the full extent of the intestine (Figure 6B). In the final median portion of the intestine, oval-shaped cells were observed, symmetrically spaced $17 \mu \mathrm{m}$ from one another (Figure 6B).

Table 1 shows the morphological information on the intramolluscan larval stages of $A$. vasorum. Although the chitinous rods were present from the L1 stage onwards, they were twice as large in L3 as those found in the other two stages. The nerve ring was three times as long in L3 $(18 \mu \mathrm{m})$ as in L1 $(6 \mu \mathrm{m})$, but only $3 \mu \mathrm{m}$ longer than in L2. The genital primordium developed greatly between the stages: it was 2.5 times smaller in L1 than in L2 and 3.5 times bigger in L3 than in L1. L2 showed the greatest distance between the genital primordium and the tail. The esophagus was more developed in L3. 

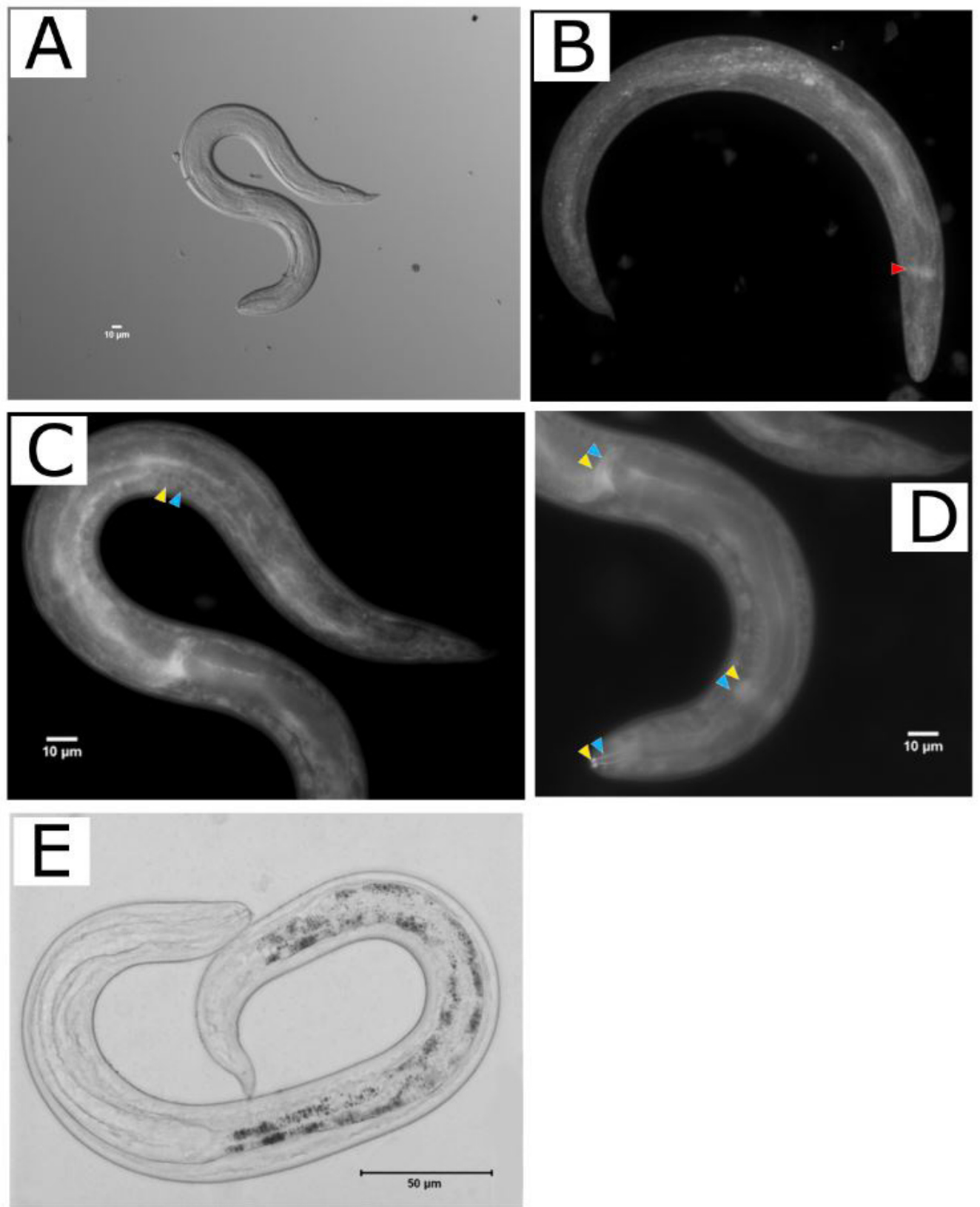

Figure 5. Third-stage larva of Angiostrongylus vasorum. (A) L3 under the light field microscope; (B) L3 with anti-collagen antibodies: red arrowhead indicates the nerve ring; (C) Posterior portion of $L 3$ with anti- $\alpha$-tubulin and anti- $\beta$-tubulin antibodies: blue and yellow arrowheads indicate genital primordial cells; (D) Anterior portion of L3 with anti-a-tubulin, indicated by blue arrowheads: anti- $\beta$-tubulin antibodies are indicated by yellow arrowheads; the arrowheads indicate the distance between the anterior end and the nerve ring and the distance between the nerve ring and the beginning of the gut; (E) Dark spots indicate lipid droplets stained with oil red $\mathrm{O}$.

Table 1. Measurements (in $\mu \mathrm{m}$ ) of the main structures of the larval stages of Angiostrongylus vasorum in the snail Achatina fulica.

\begin{tabular}{ccccccc}
\hline $\begin{array}{c}\text { Angiostrongylus } \\
\text { vasorum stage }\end{array}$ & $\begin{array}{c}\text { Chitinous } \\
\text { rods }\end{array}$ & $\begin{array}{c}\text { Nerve } \\
\text { ring }\end{array}$ & $\begin{array}{c}\text { Distance } \\
\text { from ring to } \\
\text { the anterior } \\
\text { region }\end{array}$ & Esophagus & $\begin{array}{c}\text { Genital } \\
\text { primordium }\end{array}$ & $\begin{array}{c}\text { Distance from } \\
\text { the genital } \\
\text { primordium to } \\
\text { the tail }\end{array}$ \\
\hline L1 & $7 \pm 0.2$ & $6 \pm 0.4$ & $70 \pm 1$ & $109 \pm 0.8$ & $6 \pm 0.3$ & $99 \pm 2$ \\
L2 & $6 \pm 0.3$ & $15 \pm 0.8$ & $80 \pm 3$ & $147 \pm 1$ & $15 \pm 0.4$ & $21 \pm 0.7$ \\
L3 & $13 \pm 0.5$ & $18 \pm 0.9$ & $64 \pm 4$ & $192 \pm 2$ & $156 \pm 5$ \\
\hline
\end{tabular}



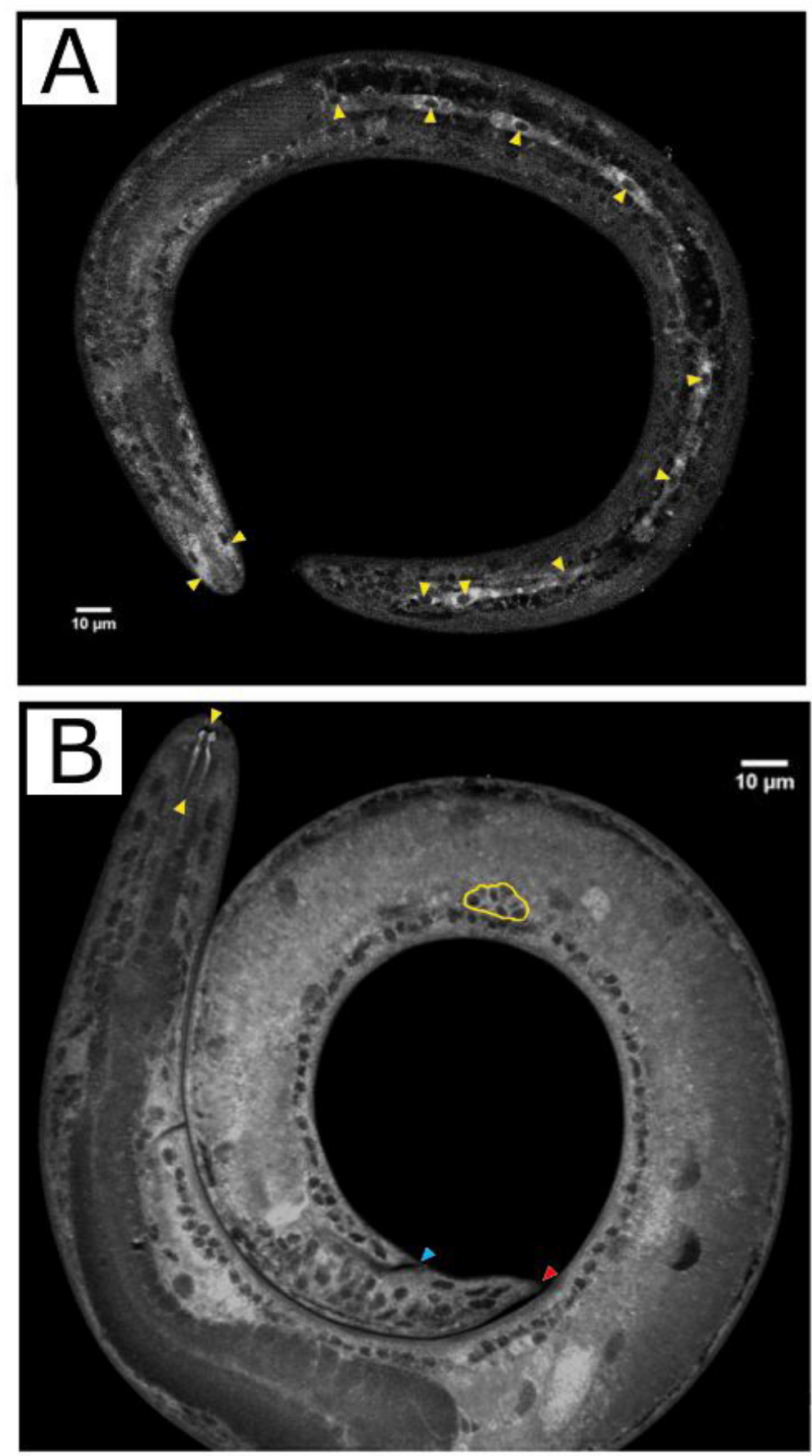

Figure 6. Third-stage larva of Angiostrongylus vasorum stained with picrosirius red. (A) Yellow arrowheads indicate the oval-shaped cellular layer spaced symmetrically along the esophagus and nerve ganglia; (B) The chitinous rods are indicated as between yellow arrowheads; the genital primordium is circled; blue arrowheads indicate the anal opening; red arrowheads indicate the tip of the tail.

\section{Discussion}

Angiostrongylus vasorum undergoes two molts inside its molluscs hosts, developing from $L 1$ to $L 2$ and then from L2 to L3. The larval stages of $A$. vasorum recovered from A. fulica were similar to those found in L1 of Arion sp., Omalonyx matheroni and Subulina octona, since L1 showed a mean length of $335 \mu \mathrm{m}$, L2 had a mean length of $420 \mu \mathrm{m}$ and L3 had a mean length of $485 \mu \mathrm{m}$, respectively (Guilhon \& Cens, 1973; Bessa et al., 2000; Mozzer et al., 2011). The morphological details presented during the development of the digestive and reproductive tracts, which begins at the larval stages of $A$. vasorum, have not been well studied so far. Here, we described these details for the L1, L2 and L3 larval stages, which are not well observed through optical field microscopy. 
In L1, the antibodies and dyes used here revealed the oral opening, the chitinous rods and a pair of rounded structures close to these, along with the nerve ring, esophagus, intestine and anal opening. Although anti- $\beta$-actin antibodies presented the least intensity, they detected the intestine and nerve ring well. We also observed prominent areas throughout the interior of L1. Using picrosirius red, we were able to detect the initial formation of the chitinous rods in the anterior region of L1. The morphology revealed here suggests that the chitinous rods are part of the oral cavity, thus indicating that the oral cavity is in the process of formation. This structure seems to be part of the digestive system of L1, which would thus be a narrow, almost closed stoma. However, in L3, a dilation between the two structures was observed. These structures were defined as chitinous rods and the dilation between them gives a stomal appearance to this apparent oral opening. The esophagus detected in L1 has a rhabditiform shape that is characteristic of the first-stage larvae, as shown by Rosen et al. (1970). The L1 intestine was well characterized at the $1^{\text {st }} \mathrm{dpi}$, in the final third of the larvae, ending in the anal opening. This observation is different from what was presented by LV et al. (2009), who found that the intestine of the L1 larvae of $A$. cantonensis had a dilated appearance only five days after infecting Pomacea canaliculata. The tail of $\mathrm{L} 1$ has an unguiform appendage shape, which is the main characteristic differentiating the L1 stage of Metastrongylidae from other parasitic nematodes (Rosen et al., 1970).

By using these markers in L2, we were able to show a pair of rounded structures, as well as the nerve ring, esophagus, gut (which presented as a compact mass occupying virtually all of the posterior portion of the larva), genital primordium and anal opening. In the oral opening, two protuberances that were not present in the other stages were found. The morphology of $L 2$ is the least studied so far, probably due to the difficulty in recovering these larvae from the molluscs' tissues. Nevertheless, it is known that L2 has two sheaths: one that originated from L1 and is being eliminated; and the other that is under development to form the sheath in L3 (Guilhon \& Afghahi, 1969; Bessa et al., 2000; Coaglio et al., 2016).

The oral opening, the chitinous rods (anti-a-tubulin, anti- $\beta$-tubulin and picrosirius red), the nervous system (anti-a-tubulin, anti- $\beta$-tubulin, anti-collagen and picrosirius red) the excretory pore (picrosirius red), the esophagus (picrosirius red), the intestine (anti-a-tubulin and anti- $\beta$-tubulin), the genital primordium (picrosirius red), the anal opening (picrosirius red) and lipid reserves in the intestine (Oil rRed O) were all detected in L3. In the final portion of the tail, after the anal opening, we observed a set of cells with symmetrical sizes that may form the structures that will arise in the future stages of the parasite in the definitive host. The esophagus formed a bulb close to the intestine.

Morphological information regarding structures such as the chitinous rods, nerve ring, excretory pore, genital primordium and esophagus has been reported for L1, L2 and L3 larvae of some metastrongyloids during intramolluscan development (López et al., 2005; Rebello et al., 2013; Coaglio et al., 2016; Colella et al., 2017). However, that information did not have the degree of detail presented here. Indeed, the present study reveals novel observations regarding chitinous rods in L1 and L2, nerve ganglia in L3, spherical structures located near the mouth region of $\mathrm{L} 2$ and lipid reserves, intense cellularity and body cavities in all three stages.

The infecting stage is L3. Angiostrongylus vasorum is characterized by the presence of a pair of chitinous rods near the mouth. Our data suggest that these structures are present from the L1 stage onwards but only reach full development in L3 when they show a space between each other. They may constitute the stoma in the adult parasite. The parasites $A$. cantonensis, $A$. costaricensis and $A$. abstrusus also present structures similar to the chitinous rods found in $A$. vasorum that are characteristic for L3. To date, there have not been any reports from any morphological studies characterizing the internal morphology of intramolluscan nematodes (Ash, 1970; Hata \& Kojima, 1990; Lv et al., 2009; Ohlweiler et al., 2010). The muscle structure that forms the intestine consists of a thick cellular assembly that ends in the anal opening. Also, the body musculature of $L 3$ is denser than that of L1. Picrosirius red strongly labelled the final portion of the intestine of L3 and therefore may be considered to be a useful tool for studying intramolluscan nematode development. The tail ends with a digitiform appendix, which a characteristic of L3 that is common to A. vasorum, A. costaricensis and A. cantonensis (Ash, 1970; Guilhon \& Cens, 1973; Hata \& Kojima, 1990; Bessa et al., 2000).

This study was the first to use antibodies to better characterize the structures of $A$. vasorum larvae. Other studies have used a similar strategy with antibody markers to characterize the structures of Schistosoma mansoni (Collins et al., 2011), Echinostoma paraensei (Souza et al., 2011), Ascaris suum (Fellowes et al., 1999; Williamson et al., 2009) and Caenorhabditis elegans (Albeg et al., 2011). Our study pioneered the use of picrosirius red to morphologically characterize parasites, since this dye had so far only been used to observe the production of collagen in histological tissue sections. For example, picrosirius red had been used on mouse liver to analyze its response when infected 
with Schistosoma mansoni (Lenzi et al., 1999) and on rat liver infected with Plasmodium berghei (Haque et al., 2011). This low-cost dye successfully stained L1, L2 and L3, thereby revealing almost all the structures that were also observed using antibodies. Staining with picrosirius red and labelling with cytoskeleton and collagen antibodies provided a more realistic view than did optical field microscopy, because these tools showed details about how the larvae are actually structured. The dyes and antibodies used here generated more detailed information about the larval structures. Therefore, future studies using these tools may help expand the current knowledge about the biological role of the structures of the larval stages of $A$. vasorum.

Staining the larvae of $A$. vasorum with Oil Red O showed the main lipid reserve sites at each larval stage. Saturated lipids are the most important energy reserves in nematodes and account for $11-67 \%$ of the dry weight of the parasite's juvenile phase, whereas neutral fats such as triglycerides are the main form of energy storage in adults (Andaló et al., 2011). The lipid reserves observed in L1 were uniformly distributed throughout the body. Lipid droplets are the main storage sites for neutral lipids (XU et al., 2012). The lipid reserve of L2, which remains immobile in the host's tissue, was found in the whole body. Mendonça et al. (2008) found similar results when staining L2 of $A$. costaricensis with Oil Red O. L3, which is the most active larval stage, spends more of its energy reserves than do the other two stages. Consequently, L3 has fewer lipid droplets concentrated in the intestine than are observed in the other larval stages.

\section{Conclusions}

Using anti- $\beta$-tubulin, anti- $\alpha$-tubulin, anti-collagen and anti- $\beta$-actin antibodies, along with picrosirius red and Oil Red $O$ staining, we revealed here unprecedented details regarding the internal morphology and morphometry of the intramolluscan larval stages of $A$. vasorum that should help expand the current understanding about the biology of this parasite. The picrosirius red dye revealed the musculature of $A$. vasorum and nerve ganglia in L3. The picrosirius red dye was better for morphological and morphometric analysis of $A$. vasorum $L 1, \mathrm{~L} 2$ and $\mathrm{L} 3$ in A. fulica, and it was also a cost-effective dye. Staining $L 1, L 2$ and $L 3$ of $A$. vasorum with Oil Red $O$ revealed that they store energy in the form of lipid droplets that change their main location as the larvae progress through their development.

\section{Acknowledgements}

We also would like to thank Marco Anacleto (Scientific Illustration Laboratory, Instituto de Ciências Biológicas, Federal University of Minas Gerais, Brazil), and Image Acquisition and Processing Center, Instituto de Ciências Biológicas, Federal University of Minas Gerais, Brazil - CAPI.

\section{References}

Albeg A, Smith CJ, Chatzigeorgiou M, Feitelson DG, Hall DH, Schafer WR, et al. C. elegans multi-dendritic sensory neurons: morphology and function. Mol Cell Neurosci 2011; 46(1): 308-317. http://dx.doi.org/10.1016/j.mcn.2010.10.001. PMid:20971193.

Andaló V, Moino A, Maximiniano C, Campos VP, Mendonça LA. Influence of temperature and duration of storage on the lipid reserves of entomopathogenic nematodes. Rev Colomb Entomol 2011; 37(2): 203-209.

Ash LR. Diagnostic morphology of the third-stage larvae of Angiostrongylus cantonensis, Angiostrongylus vasorum, Aelurostrongylus abstrusus, and Anafilaroides rostratus (Nematoda: metastrongyloidea). J Parasitol 1970; 56(2): 249-253. http://dx.doi. org/10.2307/3277651. PMid:5445821.

Barçante JMP, Barçante TA, Dias SRC, Lima WS. Ocorrência de Achatina fulica Bowdich, 1822 (Mollusca: Gastropoda: Achatinoidea) no Estado de Minas Gerais, Brasil. Bol Mus Biol Mello Leitão 2005; 18: 65-70.

Bessa ECA, Lima WS, Daemon E, Cury MC, Araújo JLB. Desenvolvimento biológico de Angiostrongylus vasorum (Baillet) Kamensnky (Nematoda, Angiostrongylidae) em Subulina octona Bruguière (Molusca, Subulinidae) em condições de laboratório. Rev Bras Zool 2000; 17(1): 29-41. http://dx.doi.org/10.1590/S0101-81752000000100004.

Coaglio AL, Mozzer LR, Corrêa DN, Pereira CAJ, Lima WS. Evaluation of techniques for recovery of Angiostrongylus vasorum from Achatina fulica, a potential intermediate host. Rev Patol Trop 2016; 45(1): 87-97. http://dx.doi.org/10.5216/rpt.v45i1.40272.

Colella V, Cavalera MA, Deak G, Tarallo VD, Gherman CM, Mihalca AD, et al. Larval development of Angiostrongylus chabaudi, the causative agent of feline angiostrongylosis, in the snail Cornu aspersum. Parasitol 2017; 144(14): 1922-1930. http://dx.doi. org/10.1017/S0031182017001433. PMid:28805181. 
Collins J J 3rd, King RS, Cogswell A, Williams DL, Newmark PA. An atlas for Schistosoma mansoni organs and life-cycle stages using cell type-specific markers and confocal microscopy. PLoS Neg/ Trop Dis 2011; 5(3): e1009. http://dx.doi.org/10.1371/journal. pntd.0001009. PMid:21408085.

Fellowes RA, Dougan PM, Maule AG, Marks NJ, Halton DW. Neuromusculature of the ovijector of Ascaris suum (Ascaroidea, nematoda): an ultrastructural and immunocytochemical study. J Comp Neurol 1999; 415(4): 518-528. http://dx.doi.org/10.1002/ (SICI)1096-9861(19991227)415:4<518::AID-CNE7>3.0.CO;2-L. PMid:10570459.

Guilhon J, Afghahi A. Larval development of Angiostrongylus vasorum (Baillet, 1866) in the body of various species of terrestrial mollusks. C R Acad Hebd Séances 'Acad Sci D 1969; 268(2): 434-436.

Guilhon J, Cens B. Angiostrongylus vasorum (Baillet, 1866). Etude biologique et morphologique. Ann Parasitol Hum Comp 1973; 48(4): 567-596. http://dx.doi.org/10.1051/parasite/1973484567. PMid:4791829.

Haque A, Best SE, Amante FH, Ammerdorffer A, de Labastida F, Pereira T, et al. High parasite burdens cause liver damage in mice following Plasmodium berghei ANKA infection independently of CD8+ T cell-mediated immune pathology. Infect Immun 2011; 79(5): 1882-1888. http://dx.doi.org/10.1128/IAI.01210-10.

Hata H, Kojima S. Angiostrongylus cantonensis: in vitro cultivation from the first-stage to infective third-stage larvae. Exp Parasitol 1990; 70(4): 476-482. http://dx.doi.org/10.1016/0014-4894(90)90132-V. PMid:2323398.

Junqueira LCU, Bignolas G, Brentani RR. Picrosirius staining plus polarization microscopy, a method for collagen detection in tissue sections. Histochem J 1979; 11(4): 447-455. http://dx.doi.org/10.1007/BF01002772. PMid:91593.

Lenzi HL, Kimmel E, Schechtman H, Pelajo-Machado M, Vale BS, Panasco MS, et al. Collagen arrangement in hepatic granuloma in mice infected with Schistosoma mansoni: dependence on fiber radiation centers. Braz J Med Biol Res 1999; 32(5): 639-643. http:// dx.doi.org/10.1590/S0100-879X1999000500018. PMid:10412576.

Lima WS, Costa HM, Guimarães MP, Leite AC. Angiostrongylus vasorum (Baillet, 1866) Nematoda: Prostostrongylidae, em cães de Minas Gerais, Brasil. Mem Inst Oswaldo Cruz 1985; 80(2): 233-235. http://dx.doi.org/10.1590/S0074-02761985000200015. PMid:3836330.

López C, Panadero R, Paz A, Sánchez-Andrade R, Díaz P, Díez-Baños P, et al. Larval development of Aelurostrongylus abstrusus (Nematoda, Angiostrongylidae) in experimentally infected Cernuella (Cernuella) virgata (Mollusca, Helicidae). Parasitol Res 2005; 95(1): 13-16. http://dx.doi.org/10.1007/s00436-004-1244-z. PMid:15614583.

Lv S, Zhang Y, Liu HX, Zhang CW, Steinmann P, Zhou XN, et al. Angiostrongylus cantonensis: morphological and behavioral investigation within the freshwater snail Pomacea canaliculata. Parasitol Res 2009; 104(6): 1351-1359. http://dx.doi.org/10.1007/ s00436-009-1334-z. PMid:19172296.

McCoy CJ, Atkinson LE, Robb E, Marks NJ, Maule AG, Mousley A. Tool-Driven Advances in Neuropeptide Research from a Nematode Parasite Perspective. Trends Parasito/ 2017; 33(12): 986-1002. http://dx.doi.org/10.1016/j.pt.2017.08.009. PMid:28986106.

Mendonça CL, Carvalho OS, Mota EM, Lenzi HL. Development of Angiostrongylus costaricensis Morera and Céspedes 1971 (Nematoda: Angiostrongylidae) larvae in the intermediate host Sarasinula marginata (Semper 1885) (Mollusca: Soleolifera). Parasitol Res 2008; 102(5): 861-865. http://dx.doi.org/10.1007/s00436-007-0834-y. PMid:18293010.

Mozzer LR, Montresor LC, Vidigal TH, Lima WS. Angiostrongylus vasorum: Experimental Infection and Larval Development in Omalonyx matheroni. J Parasitol Res 2011; 2011: 178748. http://dx.doi.org/10.1155/2011/178748. PMid:21687642.

Neuhauss E, Fitarelli M, Romanzini J, Graeff-Teixeira C. Low susceptibility of Achatina fulica from Brazil to infection with Angiostrongylus costaricensis and A. cantonensis. Mem Inst Oswaldo Cruz 2007; 102(1): 49-52. http://dx.doi.org/10.1590/S007402762007000100007. PMid:17293998.

Ohlweiler FP, Guimarães MC, Takahashi FY, Eduardo JM. Current distribution of Achatina fulica, in the state of São Paulo including records of Aelurostrongylus abstrusus (Nematoda) larvae infestation. Rev Inst Med Trop São Paulo 2010; 52(4): 211-214. http:// dx.doi.org/10.1590/S0036-46652010000400009. PMid:21748230.

Oliveira APM, Torres EJL, Maldonado AJr, Araújo JLB, Fernandez MA, Thiengo SC. Achatina fulica como hospedeiro intermediário de nematódeos de interesse médico-veterinário em Goiás, Brasil. Rev Patol Trop 2010; 39(3): 199-210.

Pereira CAJ, Martins-Souza RL, Coelho PM, Lima WS, Negrão-Corrêa D. Effect of Angiostrongylus vasorum infection on Biomphalaria tenagophila susceptibility to Schistosoma mansoni. Acta Trop 2006; 98(3): 224-233. http://dx.doi.org/10.1016/j. actatropica.2006.05.002. PMid:16750811.

Rebello KM, Menna-Barreto RF, Chagas-Moutinho VA, Mota EM, Perales J, Neves Ferreira AG, et al. Morphological aspects of Angiostrongylus costaricensis by light and scanning electron microscopy. Acta Trop 2013; 127(3): 191-198. http://dx.doi.org/10.1016/j. actatropica.2013.05.002. PMid:23685002.

Rosen L, Ash LR, Wallace GD. Life history of the canine lungworm Angiostrongylus vasorum (Baillet). Am J Vet Res 1970; 31(1): 131-143. PMid:5414275. 
Souza JG, Garcia JS, Manso PP, Neves RH, Maldonado A Jr, Machado-Silva JR. Development of the reproductive system of Echinostoma paraensei in Mesocricetus auratus analyzed by light and confocal scanning laser microscopy. Exp Parasitol 2011; 128(4): 341-346. http://dx.doi.org/10.1016/j.exppara.2011.04.005. PMid:21554877.

Thiengo SC, Simões RO, Fernandez MA, Maldonado A Jr. Angiostrongylus cantonensis and Rat Lungworm disease in Brazil. Hawaii J Med Public Health 2013;72(6 Suppl 2): 18-22. PMid:23901376.

Williamson SM, Robertson AP, Brown L, Williams T, Woods DJ, Martin RJ, et al. The nicotinic acetylcholine receptors of the parasitic nematode Ascaris suum: formation of two distinct drug targets by varying the relative expression levels of two subunits. PLoS Pathog 2009; 5(7): e1000517. http://dx.doi.org/10.1371/journal.ppat.1000517. PMid:19609360.

Xu N, Zhang SO, Cole RA, McKinney SA, Guo F, Haas JT, et al. The FATP1-DGAT2 complex facilitates lipid droplet expansion at the ER-lipid droplet interface. J Cell Biol 2012; 198(5): 895-911. http://dx.doi.org/10.1083/jcb.201201139. PMid:22927462. 